\title{
ANALYSIS OF THE POSSIBILITY OF USING KEY PERFORMANCE INDICATORS IN THE SYSTEMS OF LOGISTICS AND PRODUCTION ENTERPRISES
}

\begin{abstract}
Key Performance Indicators (KPIs) are one of the most important management tools in enterprises. Their proper implementation and application help to improve and control both the processes and the effectiveness of activities undertaken in the organization. The study aimed to analyze the degree of use of the Key Performance Indicators in information technology (IT) systems by logistics companies and manufacturing companies and to investigate possible differences in the scope of knowledge and use of KPIs between logistics and manufacturing companies. The conducted analyses indicate that production companies tend to use financial and non-financial KPIs, while logistics companies mainly use financial indicators. Based on the pilot studies, the degree of use of KPIs was assessed as high. Respondents in the survey indicated a high or very high level of efficiency in the use of KPIs in the context of general objectives of enterprises from the perspective of customers, finances, processes, and development.
\end{abstract}

Keywords: Key Performance Indicators (KPIs), Quality Management, Efficiency.

\section{INTRODUCTION}

In recent years, economic changes have contributed to the fact that both the quality of products and services as well as ISO standardization, affect innovation. These factors have become a priority criterion determining the success of enterprises (Mentel, Hajduk-Stelmachowicz, 2020; Ostasz et al, 2020; Sudoon, 2006). They can support the achievement of economic, environmental and social objectives as well as support sustainable development (Hajduk-Stelmachowicz, 2014). Equally important is the management's knowledge of the possibilities of increasing the effectiveness of work. The knowledge of management is the result of both theoretical and practical knowledge and can result in the improvement of the company's operations and processes. (Babica, Pająk, 2006;

\footnotetext{
${ }^{1}$ Andrzej Pacana, PhD, DSc, Eng, Associate Prof., Rzeszow University of Technology, Rzeszów, Aleja Powstańców Warszawy 12, 35-959 Rzeszów; e-mail: app@ prz.edu.pl (corresponding author). ORCID: 0000-0003-1121-6352.

${ }^{2}$ Karolina Czerwińska, MA, Rzeszow University of Technology, Rzeszów, Aleja Powstańców Warszawy 12, 35-959 Rzeszów; e-mail: k.czerwinska@ prz.edu.pl. ORCID: 0000-0003-1121-6352.

${ }^{3}$ Michalene Eva Grebski, PhD, Colorado Mesa University, 1100 North Avenue, Grand Junction, CO 81501 USA; e-mail: mgrebski@ coloradomesa.edu. ORCID: 0000-0003-3487-4473.
} 
Karaszewski, 2005; Wolniak, Skotnicka, 2005). Sustained and effective continuous quality improvement (CQI) can be achieved by directing the organisation's efforts towards planning, monitoring, and preventing problems right at their source (Bamford, Greatbanks, 2005; Grudowski, 2006).

Lack of feedback on the functioning of the components of the whole enterprise may be one of the reasons for the failure to achieve the objectives set. The control of the achieved results can take place in the sphere of finances, customers, processes, and development. For this reason, Key Performance Indicators (KPIs) should be seen as the tool most frequently used by managers who contribute to increasing the level of effectiveness of strategic and operational management. By monitoring the KPIs and the extent to which they have been achieved according to the objectives set, the management can be provided with information enabling them to make quick decisions, prioritise their activities and improve the company's development strategy. (Borsos, Iacob, Calefariu, 2016; Grabowska, 2017; Pacana, Czerwińska, 2020; Parmenter, 2016).

The study aims to analyse the degree of use of Key Performance Indicators in IT systems in logistics companies and manufacturing companies. The study will also examine possible differences in the scope of knowledge and use of KPIs between logistics and manufacturing companies.

\section{CHARACTERISTICS OF KEY PERFORMANCE INDICATORS (KPIS)}

Key Performance Indicators is the methodology for the application of measuring and assessment in management of an enterprise. KPIs combines both controlling of the processes and Lean Manufacturing tools. The use of key indicators is based on the rationalization and selection of an appropriate profile of indicators to facilitate the measurement and assessment of achievement of the objectives, defined by the SMART (Specific, Measurable, Achievable, Relevant, Time-bound) concept. (Czerwińska, Pacana, 2020; Drucker, 2004; Mourtzis, Fotia, Vlachou, Koutoupes, 2018; Podgórski, 2015; Zhou, He, 2018).

Key Performance Indicators are being used for the purpose of assessing the economical, technical and organizational parameters describing the functioning of the enterprise. The assessment of the KPIs will allow to identify the factors influencing the values of the performance indicators (Bartecki, Król, Skowroński, 2018; Czerwińska, Pacana, Dwornicka, 2020; Hollender 2016).

KPIs are one of the tools of Business Performance Management, i.e. a group of concepts in the field of operational management. KPIs promote the improvement and effectiveness of the organization's functioning with the use of measures, processes monitoring and performance management systems. At the same time, KPIs are an integral part of a set of global best manufacturing practices known as World Class Manufacturing (WCM). In the literature on the subject one can find over 2000 definitions of KPIs being used by organizations in diverse sectors. (Grycuk, 2010; Parmenter, 2016; Piasecka-Głuszak, 2017). Selected KPI definitions are included in Table 1.

An analysis of the attributes of KPIs listed in Table 1 allows for the formulate of the definition of performance - based indicators as follows: Key performance indicators are a method of assessing a specific process for the purpose of calculating the success rate from economical, technical, and organizational perspectives. 
Table 1. Definitions of key performance indicators

\begin{tabular}{|c|c|c|}
\hline $\begin{array}{l}\text { Num- } \\
\text { ber }\end{array}$ & Source & Definition \\
\hline 1 & $\begin{array}{l}\text { ISO 22400- } \\
1: 2019,2019\end{array}$ & $\begin{array}{l}\text { Quantifiable level of achievement of the critical objective. ISO } 22400 \\
\text { also states that key performance indicators measurements come directly } \\
\text { from the aggregation function, physical measurements, data and other } \\
\text { KPIs. }\end{array}$ \\
\hline 2 & Clifton, 2012 & $\begin{array}{l}\text { Any measure, percentage, index or average that can help an organization } \\
\text { to quickly understand incoming data in the right context and time. }\end{array}$ \\
\hline 3 & $\begin{array}{l}\text { Berrah, } \\
\text { Foulloy, } 2013\end{array}$ & $\begin{array}{l}\text { The process of measuring performance representing a relationship } \\
\text { expressed by a type of measure in combination with the target point and } \\
\text { reflecting on the objective. }\end{array}$ \\
\hline 4 & $\begin{array}{l}16 \\
16\end{array}$ & $\begin{array}{l}\text { A KPI indicates how far the organization is pursuing operational, tactical } \\
\text { or strategic objectives that are key to its current and future success. }\end{array}$ \\
\hline 5 & $\begin{array}{l}\text { Neely, Adams, } \\
\text { Kennerly, } \\
2002 \\
\end{array}$ & Parameter to quantify past performance and/or efficiency. \\
\hline 6 & $\begin{array}{l}\text { Vaser, Forconi, } \\
2015\end{array}$ & $\begin{array}{l}\text { KPI is a mathematical combination of elements called performance } \\
\text { counters or permanence indicators. The performance measures identify } \\
\text { systemic events reflected in the KPI formula and prove that something } \\
\text { has happened, e.g. failure or success in a specific networked procedure. }\end{array}$ \\
\hline 7 & 9 & Key organizational indicators that stimulate the company's performance. \\
\hline 8 & $\begin{array}{l}\text { Melnyk, Bititci, } \\
\text { Platts, Tobias, } \\
\text { Anderson, } 2014 \\
\end{array}$ & $\begin{array}{l}\text { It is a tool to measure efficiency and/or effectiveness and is therefore both } \\
\text { measurable and verifiable. }\end{array}$ \\
\hline 9 & $\begin{array}{l}\text { Ortega, } \\
2012\end{array}$ & $\begin{array}{l}\text { Financial and non-financial indicators used to determine achievements } \\
\text { over time towards achieving operational and strategic objectives. }\end{array}$ \\
\hline 10 & Enns, 2005 & $\begin{array}{l}\text { KPIs are parameters that show the condition of the company and its } \\
\text { business development system. They combine the company's objectives } \\
\text { and strategies with its results, outputs. KPIs provide management with } \\
\text { past, current and future status information. }\end{array}$ \\
\hline 11 & $\begin{array}{l}\text { Al-Mutairi, } \\
2012\end{array}$ & $\begin{array}{l}\text { Key performance indicators are commonly used by companies as a tool } \\
\text { to assess performance. They form the basis for a system of achievements } \\
\text { that turn the company's long-term strategic goals into short-term ones. } \\
\text { The establishment of a clear and able to be assessed indicators are critical. } \\
\text { KPIs facilitate good performance management. }\end{array}$ \\
\hline 12 & $\begin{array}{l}\text { Rolo, Pires, } \\
\text { Saraiva, } \\
2014\end{array}$ & $\begin{array}{l}\text { They are measures of the achievements of processes in an organization. } \\
\text { They are used as communication tools between the management and the } \\
\text { lower levels of the organisational structure. KPIs also reinforce the } \\
\text { organisations mission and vision. Key performance indicators can also be } \\
\text { used to measure the performance of the network, which makes it possible } \\
\text { to set targets for achievement and the effectiveness of the entire } \\
\text { organisation }\end{array}$ \\
\hline
\end{tabular}

Source: own study based on: (Neely Adams, Kennerly, 2002; Clifton, 2012; Berrah, Foulloy, 2013; Onyemeh, Lee, Iqbal, 2016; ISO 22400-1:2014, 2014; Vaser, Forconi, 2015; Melnyk Bititci, Platts, Tobias, Anderson, 2014; Ortega, 2012; Enns, 2005; Al-Mutairi, 2012; Rolo, Pires, Saraiva, 2014). 
Key performance indicators need to identify the priorities of the actions needed to improve the process and actions needed to mobilize the workforce to reach the goals and strategies of the enterprise.

\section{METHODOLOGY OF THE STUDIES}

The research methodology adopted in the study includes a survey questionnaire. The first stage of the pilot study was addressed to a group of 50 manufacturing companies and 40 logistics companies. The survey aimed to check the knowledge of selected KPIs - a set of current and forecasting measures based on four perspectives:

- customers,

- finances,

- processes, and

- development.

These groups can be extended with relevant indicators used by the enterprises. The target group of respondents were people employed in positions from the area of operational management, such as:

- directors,

- production managers,

- sales managers,

- quality specialists,

- quantity specialists

- quality managers, and

- project managers.

The research was conducted in enterprises located in the southeastern part of Poland.

The second stage of the research was related to the analysis of the knowledge of KPIs within the selected groups manufacturing and logistics entrepreneurs. The survey was conducted in sixty companies (31 production companies and 29 logistics companies). Respondents were chosen deliberately - as was the case in the first stage of the research. Fig. 1 shows a diagram of the procedure presented in the study. 


\begin{tabular}{|c|c|}
\hline $\begin{array}{l}\text { Identification of groups of Key } \\
\text { Performance Indicators }\end{array}$ & $\begin{array}{l}\text { Analysis of the literature and standards ISO } \\
22400-1: 2014 \text { and ISO 22400-2:2014. }\end{array}$ \\
\hline \multicolumn{2}{|l|}{$\nabla$} \\
\hline $\begin{array}{l}\text { Identifying Key Performance } \\
\text { Indicators used in enterprises }\end{array}$ & $\begin{array}{l}\text { A questionnaire containing open questions on } \\
\text { what kind of KPIs are used within the } \\
\text { company's specified groups }\end{array}$ \\
\hline \multicolumn{2}{|l|}{$\nabla$} \\
\hline $\begin{array}{l}\text { Survey of the level of KPI } \\
\text { knowledge by management in } \\
\text { manufacturing and logistics } \\
\text { companies }\end{array}$ & $\begin{array}{l}\text { Questionnaire with open and closed questions } \\
\text { on the knowledge and application of KPIs in } \\
\text { manufacturing and logistics companies }\end{array}$ \\
\hline \multicolumn{2}{|l|}{$\nabla$} \\
\hline $\begin{array}{l}\text { Evaluation of the effectiveness of } \\
\text { the use of KPIs in relation to } \\
\text { specific objectives in enterprises }\end{array}$ & $\begin{array}{l}\text { Face-to-face interviews to assess the } \\
\text { effectiveness of the application of KPIs in } \\
\text { relation to specific targets in enterprises }\end{array}$ \\
\hline \multicolumn{2}{|l|}{$\nabla$} \\
\hline Comparative analysis & $\begin{array}{l}\text { Comparison of results between manufacturing } \\
\text { and logistics companies }\end{array}$ \\
\hline
\end{tabular}

Fig. 1. Research methodology

In the face-to-face interviews, the respondents were asked to express their opinion on the effectiveness of the application of KPIs in relation to the objectives set in their enterprises. The research is concluded with a comparative analysis of results obtained in manufacturing and logistics companies.

\section{RESEARCH RESULTS AND ANALYSIS}

As the type of KPI influences the way it is used (Corbin 2009; Kaganski, Paavel, Lavin, 2014) and the type of measurements determines its impact on other measures of this type (Germany, 2019), it is important to classify the KPIs. KPIs can be divided into financial and non-financial (Kaplan, Norton 1996). In the first part of the survey, it was decided to check what kind of measures are used in companies to assess performance (Table 2). 
Table 2. Answers to the question: "What kind of method of measurement is used in your company to measure performance?"

\begin{tabular}{|l|c|c|}
\hline \multicolumn{1}{|c|}{ Answers } & Production companies & Logistics companies \\
\hline Mainly or exclusively financial & $36 \%$ & $53 \%$ \\
\hline Mainly non-financial & $14 \%$ & $5 \%$ \\
\hline Both financial and non-financial & $46 \%$ & $33 \%$ \\
\hline $\begin{array}{l}\text { None of the methods of } \\
\text { measurement are used }\end{array}$ & $4 \%$ & $10 \%$ \\
\hline
\end{tabular}

Financial measures are expressed in monetary units or a something related to monetary units. They are generally treated as objective because they come from an accounting system and therefore generally represent a reliable assessment of the company. This may be the reason for the large number of companies that have indicated that they predominantly use such performance measures. Due to the specificity of logistics companies, the use of financial indicators dominates. Non-financial measures are often expressed in physical units and represent complex issues that often require a personalized approach. The use of nonfinancial indicators is challenging as it requires interaction between the accounting department and other organizational units of the company and the integration of existing information systems with other departments into coherent unit. Non-financial indicators are more frequently used by manufacturing companies. However, the most common solution for manufacturing companies is to use both financial and non-financial performance measures.

The conducted survey made it possible to identify a list of indicators most frequently used within the enterprises. The allowed for a significant reduction in the number of KPIs which need to be considered and that facilitated further analyses. Table 3 identified KPIs within the framework from such perspectives as: customers, finances, processes and development and the number of measures used in assessing of individual KPIs.

Table 3. Level of use of KPIs by IT systems in manufacturing and logistics companies

\begin{tabular}{|c|c|c|}
\hline KPI meter & $\begin{array}{l}\text { Production } \\
\text { companies }\end{array}$ & $\begin{array}{l}\text { Logistics } \\
\text { companies }\end{array}$ \\
\hline \multicolumn{3}{|l|}{ Customer perspective } \\
\hline Number of newly acquired customers in specific periods of time. & $93.5 \%$ & $89.7 \%$ \\
\hline $\begin{array}{l}\text { Number and value of lost orders broken down by customers and } \\
\text { time periods. }\end{array}$ & $64.5 \%$ & $72.4 \%$ \\
\hline $\begin{array}{l}\text { Total and detailed value of orders from individual customers in the } \\
\text { given reporting periods. }\end{array}$ & $71.0 \%$ & $75.9 \%$ \\
\hline $\begin{array}{l}\text { Customer Value Coefficient (necessary to introduce customer } \\
\text { segmentation). }\end{array}$ & $61.3 \%$ & $82.8 \%$ \\
\hline Customer satisfaction rate for services or goods supplied. & $90.3 \%$ & $86.2 \%$ \\
\hline
\end{tabular}


Table 3 (cont.). Level of use of KPIs by IT systems in manufacturing and logistics companies

\begin{tabular}{|c|c|c|}
\hline KPI meter & $\begin{array}{l}\text { Production } \\
\text { companies }\end{array}$ & $\begin{array}{l}\text { Logistics } \\
\text { companies }\end{array}$ \\
\hline \multicolumn{3}{|l|}{ Financial perspective } \\
\hline Average cost of order processing. & $74.2 \%$ & $89.7 \%$ \\
\hline Amount of losses incurred due to lost orders. & $58.1 \%$ & $72.4 \%$ \\
\hline $\begin{array}{l}\text { Comparison of revenue and costs by department and the entire } \\
\text { company. }\end{array}$ & $100.0 \%$ & $96.6 \%$ \\
\hline Value of overdue receivables. & $48.4 \%$ & $62.1 \%$ \\
\hline Cash flow. & $96.8 \%$ & $100.0 \%$ \\
\hline Financial result of the company. & $100.0 \%$ & $100.0 \%$ \\
\hline \multicolumn{3}{|l|}{ Process perspective } \\
\hline Number of employees involved in order processing. & $71.0 \%$ & $65.5 \%$ \\
\hline $\begin{array}{l}\text { Order processing time from the moment of placing an order to the } \\
\text { moment of confirmation of receipt by the customer. }\end{array}$ & $87.1 \%$ & $86.2 \%$ \\
\hline $\begin{array}{l}\text { Waiting time for implementation at individual stages of the order } \\
\text { being processed by the company. }\end{array}$ & $90.3 \%$ & $41.4 \%$ \\
\hline Average waiting time for deliveries. & $87.1 \%$ & $51.7 \%$ \\
\hline Value of deviations from confirmed prices and delivery dates. & $80.6 \%$ & $79.3 \%$ \\
\hline $\begin{array}{l}\text { The rate of rotation of goods in the warehouse in correlation with } \\
\text { the demand for goods generated by the company. }\end{array}$ & $83.9 \%$ & $82.8 \%$ \\
\hline \multicolumn{3}{|l|}{ Development perspective } \\
\hline $\begin{array}{l}\text { Numbers of newly acquired foreign customers in specific time } \\
\text { frames. }\end{array}$ & $90,3 \%$ & $96,6 \%$ \\
\hline $\begin{array}{l}\text { Differences in the labour intensity of departments, processes, } \\
\text { production operations as a result of implementing new technologies } \\
\text { and equipment. }\end{array}$ & $77.4 \%$ & $34.5 \%$ \\
\hline Costs of importing products/goods. & $74.2 \%$ & $86.2 \%$ \\
\hline $\begin{array}{l}\text { Standardisation of the company's position concerning its } \\
\text { competitors, based on industry rankings and independent } \\
\text { comparative studies. }\end{array}$ & $67.7 \%$ & $72.4 \%$ \\
\hline Cost-benefit ratio of conducted market campaigns. & $80.6 \%$ & $86.2 \%$ \\
\hline
\end{tabular}

When analysing the data (level of use of KPI) obtained from the customer perspective, comparable values can be found among manufacturing and logistics companies. Only indications of the customer value ratio, which is needed to introduce customer segmentation, turned out to be smaller among manufacturing companies $(21.5 \%$ difference). From a financial perspective, all the measures indicated in the survey are more popular among logistics companies, while the opposite trend has been observed in the case of the measures singled out under the process perspective. This trend may result from the specificity of the studied groups of enterprises. As far as the development perspective is concerned, the level of use of the surveyed measures can be considered comparable. The exception is a measure indicating differences in labour intensity of departments, processes, production operations as a result of the implementation of new technologies and equipment, which is more applicable to production companies. 
The third stage of the research was direct interviews conducted in thirty-one manufacturing companies and twenty-nine logistics companies. The persons participating in the face-to-face interviews were specialists within specific departments. They were operational positions in companies. At this stage, the study aimed to assess the effectiveness of the use of KPIs concerning specific objectives of the enterprises.

The level of effectiveness is defined in a 5-step scale, where 1 means lowest effectiveness and 5 means highest effectiveness.

Table 4. Evaluation of the effectiveness of the KPIs

\begin{tabular}{|c|c|c|c|}
\hline \multirow[t]{2}{*}{ Perspective } & \multirow[t]{2}{*}{ General objective of the company } & \multicolumn{2}{|c|}{$\begin{array}{c}\text { Average assessment of the } \\
\text { effectiveness of KPIs } \\
\text { compared to objectives } \\
\end{array}$} \\
\hline & & $\begin{array}{l}\text { Production } \\
\text { companies }\end{array}$ & $\begin{array}{c}\text { Logistics } \\
\text { companies }\end{array}$ \\
\hline \multirow{3}{*}{$\begin{array}{l}\text { Customer } \\
\text { perspective }\end{array}$} & New customers. & \multirow{3}{*}{4.54} & \multirow{3}{*}{4.41} \\
\hline & $\begin{array}{l}\text { Improving the quality of service for existing } \\
\text { customers (extending the offer, improving the } \\
\text { speed of distribution of goods to customers and } \\
\text { from suppliers, after-sales services). }\end{array}$ & & \\
\hline & Reducing customer service costs. & & \\
\hline \multirow{4}{*}{$\begin{array}{l}\text { Financial } \\
\text { perspective }\end{array}$} & Analysis of the profitability of orders. & \multirow{4}{*}{4.93} & \multirow{4}{*}{4.87} \\
\hline & $\begin{array}{l}\text { Identification of the goods and customers with } \\
\text { the highest profits and losses. }\end{array}$ & & \\
\hline & Increase in the company's capital. & & \\
\hline & Increasing the company's profitability. & & \\
\hline \multirow{4}{*}{$\begin{array}{l}\text { Process } \\
\text { perspective }\end{array}$} & Improving information flow. & \multirow{4}{*}{4.67} & \multirow{4}{*}{4.03} \\
\hline & $\begin{array}{l}\text { Optimization of internal processes related to } \\
\text { customer service and delivery service. }\end{array}$ & & \\
\hline & $\begin{array}{l}\text { Optimization of internal processes related to } \\
\text { product manufacturing. }\end{array}$ & & \\
\hline & Stock optimisation. & & \\
\hline \multirow{5}{*}{$\begin{array}{l}\text { Develop- } \\
\text { ment } \\
\text { perspective }\end{array}$} & $\begin{array}{l}\text { Extension of the territorial coverage of the } \\
\text { service. }\end{array}$ & \multirow{5}{*}{4.29} & \multirow{5}{*}{4.16} \\
\hline & Expansion into foreign markets. & & \\
\hline & $\begin{array}{l}\text { Increasing work efficiency by investing in } \\
\text { modern technologies and equipment. }\end{array}$ & & \\
\hline & Increasing the company's market advantage. & & \\
\hline & $\begin{array}{l}\text { Effective human resources management. } \\
\text { Attracting new and retaining qualified } \\
\text { employees. }\end{array}$ & & \\
\hline
\end{tabular}

In terms of the effectiveness of the application of KPIs, the respondents assess the usefulness of the examined perspectives at a high or very high level. According to the respondents from manufacturing and logistics companies, the most effective indicators are financial indicators. 


\section{CONCLUSION}

The KPIs implemented and used in enterprises should be periodically evaluated. Identifying and analyzing them is an important element of management. Employees should have knowledge of their use and the actions to be taken on the basis of the information provided by the indicators. The KPIs allow to determine if the company is on the right track to achieve its objectives and strategy. They also help to identify what is changing in the company and assess the direction of these changes.

The aim of the study was to analyse the degree of use of the Key Performance Indicators (KPIs) in information technology (IT) systems in logistics companies and manufacturing companies and to examine possible differences in the scope of knowledge and use of KPIs between logistics and manufacturing companies.

According to the KPI classification, financial and non-financial measures can be distinguished. On the basis of the pilot studies, it can be concluded that production companies tend to use both types of indicators, while logistics companies mainly use financial indicators.

Employing a strategy of measuring implemented KPIs means a conscious approach of the company to investigate the causes of bad or good business practices and results. Respondents in the survey indicated a high or very high level of effectiveness of use KPIs related to general objectives of enterprises within the perspective of customers, finances, processes and development. However, it should be remembered that KPI do not guarantee a success. Considering the experience and knowledge within the organization combined with the conscious use of the KPIs, increase the chance of choosing a strategy with positive results.

\section{REFERENCES}

Al-Mutairi S. H. (2012). Cost maintenance management, eWork and eBusiness in Architecture, Engineering and Construction. Proceedings of the European Conference on Product and Process Modelling.

Babica, M., Pająk, E. (2006). Koncepcja metody eliminacji niezgodności w procesach produkcyjnych. ,Zeszyty Naukowe Politechniki Poznańskiej, Budowa Maszyn i Zarzadzanie Produkcja".

Bamford, D. R., Greatbanks, R. W. (2005). The use of quality management tools and techniques: a study of application in everyday situations. "International Journal of Quality \& Reliability Management".

Bartecki, K., Król, D., Skowroński, J. (2018). Wyznaczanie kluczowych wskaźników wydajności procesu produkcyjnego - część I: badania teoretyczne. „Pomiary. Automatyka. Robotyka”, R. 22, nr 3.

Berrah, L., Foulloy, L. (2013). Towards a unified descriptive framework for industrial objective declaration and performance measurement. "Computers in Industry", 64.

Borsos, G., Iacob, CC., Calefariu, G. (2016), The use KPI's to determine the waste in production proces, 20th Innovative Manufacturing Engineering And Energy Conference (Imanee 2016), IOP Conference Series-Materials Science and Engineering, Vol. 161.

Clifton, B. (2012). Advanced Web Metrics. Indianapolis: John Wiley \& Sons Inc.

Cobin, C. (2009). Creating effective performance measures, November 1. 
Czerwińska, K., Pacana, A. (2020). Analysis of the exterior door production process using key performance indicators (KPI). „Zarządzanie Przedsiębiorstwem” / Polskie Towarzystwo Zarządzania Produkcją, 23, 1.

Czerwińska, K., Pacana, A., Dwornicka, R. (2020). Improvement of the production process with the use of selected KPIs. "System Safety: Human - Technical Facility - Environment", Vol. 2, Issue 1.

Drucker, F. P. (2004). Zawód menedżer. Warszawa: Wydawnictwo MT Biznes.

Enns, B. (2005). Key performance indicators for new business development, Critical Briefings for the Business of Persuasion.

Grabowska, S. (2017). Kluczowe wskaźniki efektywności - studium przypadku. „Zeszyty Naukowe Politechniki Ślaskiej, Seria: Organizacja i Zarządzanie” z. 108, Politechnika Śląska.

Grudowski, P. (2006). Pomiary, analiza i doskonalenie jako kryteria auditu systemu zarzadzania jakością. „Problemy Jakości”.

Grycuk, A. (2010). Kluczowe wskaźniki efektywności (KPI) jako narzędzie doskonalenia efektywności operacyjnej firm produkcyjnych zorientowanych na lean. „Przeglad Organizacji” nr 2.

Hajduk-Stelmachowicz, M. (2014). Znaczenie strategii proekologicznych $w$ kontekście budowania przewagi konkurencyjnej przedsiębiorstw. „Prace Naukowe Uniwersytetu Ekonomicznego we Wrocławiu, Zarzadzanie Strategiczne w Teorii i Praktyce" nr 366.

Hollender, M., Chioua, M., Schlake, J., Merkert, L., Petersen, H. (2016). KPI-based Process Operation Management of highly automated processes, Institut für Regelungs- und Steuerungssysteme (IRS), ISSN: 0178-2320, 2190-4111, 2364-3137.

ISO 22400-1:2014 (2014). Automation systems and integration - Key performance indicators (KPIs) for manufacturing operations management. Part 1: Overview, concepts and terminology.

Kaganski, S., Paavel, M., Lavin, J. (2014). Selecting key performance indicators with support of enterprise analyze model. Proceedings of the International Conference of DAAAM Baltic "Industrial Engineering".

Kaplan, R. S., Norton, D. P. (1996). The Balanced Scorecard: Translating Strategy into Action. Harvard Business School Press, Boston.

Karaszewski, R. (2005). Zarzadzanie jakościa - koncepcje, metody, narzędzia stosowane przez liderów światowego biznesu. Toruń: TNOiK.

Melnyk S. A., Bititci U. S., Platts K., Tobias J., Anderson B. (2014). Is performance measurement and management fit for the future? "Management Accounting Research" 25(2).

Mentel, U., Hajduk-Stelmachowicz, M. (2020). Does standardization have an impact on innovation activity in different countries? "Problems and Perspectives in Management", 18(4).

Mourtzis, D., Fotia, S., Vlachou, E., Koutoupes, A. (2018). A Lean PSS design and evaluation framework supported by KPI monitoring and context sensitivity tools. "The International Journal of Advanced Manufacturing Technology", Vol. 94.

Neely, A., Adams, C., Kennerly, M. (2002). The Performance Prism: The Scorecard for Measuring and Managing Business Success. London: Pearson Education Limited.

Niemiec, A. (2019). Kluczowe mierniki dokonań (KPI) w zarządzaniu organizacją na gruncie teorii równowagi funkcjonalnej. Warszawa: $\mathrm{CeDeWu}$. 
Onyemeh, N. C., Lee, C. W., Iqbal, M. A. (2016). Key performance indicators for operational quality in the oil and gas industry a case study approach. IEEE International Conference on Industrial Engineering and Engineering Management.

Ortega, A. (2012). On the definition and Analysis of Process Performance Indicators. Sevilla: University of Sevilla.

Ostasz, G., Czerwińska, K., Pacana, A. (2020). Quality management of aluminum pistons with the use of quality control points. "Management Systems in Production Engineering”.

Pacana, A., Czerwińska, K. (2020), Kluczowe wskaźniki efektywności - KPI. „Management and Quality - Zarzadzanie i Jakość", Towarzystwo Naukowe Organizacji i Kierownictwa Oddział w Katowicach. Katowice: TNOiK.

Parmenter, D. (2016). Kluczowe wskaźniki efektywności (KPI). Tworzenie, wdrażanie $i$ stosowanie. Gliwice: Helion.

Piasecka-Głuszak, A. (2017). Implementacja world class manufacturing w przedsiębiorstwie produkcyjnym na rynku polskim. „Ekonomia XXI Wieku” nr 4(16).

Podgórski, D. (2015). Measuring operational performance of OSH management system A demonstration of AHP-based selection of leading key performance indicators. "Safety Science” No. 73.

Rolo, A., Pires, A. R., Saraiva, M. (2014). Supply chain as a collaborative virtual network based on larg strategy. "Advances in Intelligent Systems and Computing”, 280.

Sudoł, S. (2006). Przedsiębiorstwo. Podstawy nauki o przedsiębiorstwie. Zarzadzanie przedsiębiorstwem. Warszawa: PWE.

Vaser, M., Forconi, S. (2015). QoS KPI and QoE KQI Relationship for LTE Video Streaming and VoLTE Services, Proceedings - NGMAST 2015: The $9^{\text {th }}$ International Conference on Next Generation Mobile Applications, Services and Technologies.

Wolniak, R., Skotnicka, B. (2005). Metody i narzędzi zarządzania jakością. Teoria i praktyka. Gliwice: Wydawnictwo Politechniki Śląskiej.

DOI: 10.7862/rz.2021.mmr.04

The text was submitted to the editorial office: January 2021.

The text was accepted for publication: March 2021. 
